УДК 342.9

DOI https://doi.org/10.32844/2618-1258.2019.5-2.2

КОРОТЮК О.В.

\title{
ОСНОВНІ АСПЕКТИ ПОРУШЕННЯ ПРАВА НА ОБ'СКТИ ПРАВА ІНТЕЛЕКТУАЛЬНОЇ ВЛАСНОСТІ НА ЗАХІДНОУКРАЇНСЬКИХ ЗЕМЛЯХ ЗА АВСТРІЙСЬКИМ ЗАКОНОДАВСТВОМ ПЕРІОДУ АВСТРО-УГОРСЬКОЇ ІМПЕРІЇ (ХІХ - ПОЧАТОК ХХ СТОЛІТЬ)
}

У статті проведено аналіз кримінально-правових положень Австро-Угорщини (XIX - початок XX століть), які передбачали відповідальність за посягання на об'єкти права інтелектуальної власності. Автором розглянуто особливості кримінально-правової охорони об'єктів авторського права і права промислової власності. Встановлено, що спеціальне законодавство, яке врегульовувало питання створення, впровадження в обіг і використання об'єктів права інтелектуальної власності, було складовою частиною кримінального законодавства того часу. Врегулюванню питань кримінальної відповідальності за посягання на об'єкти авторського права законодавцем приділялася значна увага. Зокрема, особи, які мали повноваження щодо випуску у світ і розповсюдження друкованих творів різних видів, виділялися законодавцем як спеціальні суб'єкти злочинів, що було пов'язано із можливістю впливу на громадську думку шляхом випуску у світ друкованої продукції. Державне регулювання випуску у світ друкованої продукції, а також її подальше розповсюдження, здійснювалося за рахунок законодавчих положень, що містили заборони щодо змісту творів, які можуть впроваджуватися в товарний оборот, а також кримінально-правових норм, які стосувалися незаконного копіювання і розповсюдження творів. Кримінальна відповідальність за незаконне розголошення таємниць була передбачена в одній нормі. Кримінальна відповідальність за порушення прав патентовласників, прав власників промислових зразків, а також власників торгових марок передбачалася у положеннях окремих законів (патентів).

Ключові слова: інтелектуальна власність, об'єкт права інтелектуальної власності, Австро-Угорщина, кримінальна відповідальність, кримінальне законодавство.

The criminal law of Austria and Austro-Hungary (XIX - early XX centuries) which included responsibility for crimes against objects of intellectual property was analyzed in the article. The author considered the features of criminal law protection of the objects of copyright and industrial property rights. The current rules of Austrian law that established liability for crimes against objects of intellectual property show that the apparition of criminal law protection took place somewhat later than the appearance of their legal protection at all, which appeared in 1811. It was established that special legislation which regulated the issues of the creation, introduction into circulation and using objects of intellectual property, had been an integral part of the criminal law of that time. The legislator paid considerable attention to the regulation of issues of criminal responsibility for crimes against objects of copyright. In particular, individuals who had the authorities to publish and distribute printed works of various types were allocated by the legislator as special subjects of crimes, which was associated with the possibility of influencing public opinion by releasing of printed works. These subjects included such as: author, translator, publisher, distributor, bookseller and printer, and in the case of a crime in periodicals - the editor and all persons involved into the publication and distribution of the publication. The law also established the possibility of committing a crime "through periodicals". The state regulation of publishing printed products, as well as its further distribution, was carried out at the expense of legislative provisions containing prohi-

(C) КОРОТЮК О.В. - кандидат юридичних наук, докторант кафедри кримінального права та кримінології (Дніпропетровський державний університет внутрішніх справ) 
bitions for the content of works that could be implemented in commodity circulation, as well as the criminal law that concerned the illegal copying and distribution of works. Criminal responsibility for unlawful disclosure of secrets was foreseen in one norm. It was noted about "disclosure of official secrets, that were trusted to a person" and about "destruction of a document entrusted to a person because of person's authorities, or disclosure to someone some secret that is contrary to duties" in this norm. Criminal liability for violation of the rights of patent holders, rights of owners of industrial designs, as well as trademarks owners was foreseen in the provisions of separate laws (patents).

General construction of the Penal Code of 1852, as well as the criminal law of Russian Empire, took place with the principle of priority of the interests of state over the interests of man. In this historical period the priority of the public interest over the private directly influenced the main approaches to the formation of the concept of legal protection of intellectual property objects. Despite the fact that the law provided for the possibility of protecting the rights of the author of the intellectual property object (for example in the form of civil-law compensation), there was the intellectual property object in the centre of law protection.

This was manifested in the fact that criminal law was directed first of all to ensure the implementation of state control over the circulation of printed works as well as other intellectual property objects, and not to protect the rights of the creators of the relevant objects. Gradually this approach was replaced by another one, in which the key link in the legal protection of intellectual property objects had become the author. It happened in the second half of the nineteenth century with the development of international standards of legal protection and the adoption of the Berne Convention in 1886. The formation of this approach influenced the perception of the creator of the intellectual property object as a victim that is an obligatory component of the object of criminal law protection.

Key words: intellectual property, intellectual property object, Austro-Hungary, criminal responsibility, criminal legislation.

Вступ. Становлення і розвиток концепції права інтелектуальної власності в Україні відбувалося з урахуванням перебування західноукраїнських земель у складі Австрійської та АвстроУгорської імперій та Речі Посполитої, а іншої частини України - у складі Російської імперії. Окремі аспекти аналізу кримінально-правових положень, що застосовувалися на вказаних територіях впродовж XIX - початку XX століть, були розглянуті у роботах П.С. Берзіна [1; 2], Р.А. Волинця [3], Г.В. Довгань [5], А.С. Нерсесяна [7], В.Б. Харченка [8] та деяких інших. Разом 3 тим особливості кримінально-правових норм Австро-Угорської імперії (далі - Австро-Угорщина), що передбачали кримінальну відповідальність за посягання на об'єкти права інтелектуальної власності, не підлягали комплексному вивченню. Тому доцільним і актуальним видається розглянути ці кримінально-правові положення.

Постановка завдання. Метою статті $є$ аналіз основних аспектів порушення права на об'єкти права інтелектуальної власності на західноукраїнських землях за австрійським законодавством періоду Австро-Угорської імперії (XIX - початок XX століть).

Результати дослідження. Аналіз тогочасних норм австрійського законодавства, які установлювали відповідальність за незаконні посягання на об'єкти права інтелектуальної власності, показує, що виникнення кримінально-правової охорони відбулося дещо пізніше появи їх правової охорони у межах так званого «некримінального законодавства», яка з'явилася у 1811 році. У літературі відзначається, що на початку XIX ст. кримінальна відповідальність за порушення правил використання об'єктів авторського права була відсутня [4, с. 34]. Поява перших норм щодо відповідальності за незаконне використання, копіювання творів пов'язується із прийняттям Закону про літературну, музичну та художню власність 1846 року [5, с. 42]. Важливо врахувати той факт, що у системі карного права Австрійської та Австро-Угорської імперій існували «додаткові карні закони». Положення таких «додаткових» законів визначали специфічні різновиди караних діянь, що передбачались у Карному уложенні, та такі карані діяння, які цим Уложенням не передбачались (тобто додатково встановлювали види караних діянь, які в Карному уложенні прямо не закріплювались), а також встановлювали покарання за їх вчинення [1, с. 68; 2, с. 256-267]. Отже, кримінальне законодавство, що передбачало відповідальність за посягання на об'єкти права інтелектуальної власності, включало у себе положення не тільки, власне, кримінального закону, але й спеціального закону (патенту), що врегульовував питання використання об'єктів авторського 
права. Так, у Законі про захист літературної та художньої власності від несанкціонованої публікації, передруку і відтворення від 1846 року містилися положення щодо покарання за порушення авторського права (у тому числі окремі положення, що стосувалися кримінального покарання). Згідно із §4 цього Закону порушенням вважалася дія, «коли хтось використовував «механічні способи» для дублювання роботи, зокрема, незаконний передрук або щось подібне» [9]. Покаранням за такі порушення у більшості випадків був штраф, який, однак, у разі неспроможності винного щодо його сплати, міг бути замінений тюремним ув'язненням (§25-27 Закону). Окрім того, законний автор або його правонаступники мали право на компенсацію (§27). Ці порушення вважалися «тяжким поліцейським проступком» та підлягали розслідуванню за заявою потерпілої особи. При цьому допускалося виготовлення копії твору для приватного використання, а порушенням прав автора визнавалося тільки таке копіювання, що було призначено для комерційної мети [9]. Згідно із §31 Закону штрафом (а за неможливості його сплати - арештом) каралося незаконне публічне виконання драматичного або музичного твору, цілого чи з несуттєвими змінами або скороченнями, вчинене всупереч винятковим правам автора чи його правонаступників [4, с. 35]. 3 цього вбачається, що спеціальне законодавство, що врегульовувало питання створення, впровадження в обіг і використання об'єктів права інтелектуальної власності, було складовою частиною кримінального законодавства того часу.

Аналіз кримінально-правових положень Австро-Угорщини дозволяє зробити висновок про те, що врегулюванню питань кримінальної відповідальності за посягання на об'єкти авторського права законодавцем приділялася значна увага. У ст. II Кримінального уложення 1852 року відзначалося про те, що «використання у діючому кримінальному уложенні термінів «брошура» або «друковані видання» включає в себе не тільки продукцію друку, але й усі вироби, виготовлені за допомогою друку на камені, металі або дереві, тиснення, відтиски або вироби, отримані шляхом механічного чи хімічного копіювання, а також твори образотворчого мистецтва (літературні та художні твори)» [12]. Окремою нормою визначалися особи, які можуть бути суб'єктами злочинів, що вчиняються «через зміст друкованих видань» (§7). До таких суб’єктів належали: автор, перекладач, видавець, розповсюджувач, книготорговець та печатник, а у разі вчинення діяння у періодичних виданнях - також редактор і усі особи, що беруть участь у публікації та розповсюдженні видання. Згідно із $§ 10$ Уложення моментом вчинення діяння вказаними вище особами визнавався момент здачі в друк видання, а для інших винних осіб - момент, що є початком їх участі у діянні [12].

Наведені кримінально-правові положення свідчать про те, що особа, що займалася діяльністю, пов'язаною із випуском у світ друкованої продукції, визнавалася законодавцем як така, що володіє особливим правовим статусом і специфічними повноваженнями. Це зумовило створення законодавцем окремих спеціальних норм, які позначали склади діянь, що посягають на відповідну групу об'єктів права інтелектуальної власності, а також розгляд осіб, що мали повноваження щодо випуску у світ і розповсюдження друкованих творів різних видів, як спеціальних суб'єктів злочинів. На особливе значення цих повноважень вказує і те, що згідно із §26 Уложення одним із правових наслідків винесення особі вироку за вчинення караного діяння було виключення іiї із числа відповідальних редакторів друкованих видань, а також передбачення законодавцем додаткових правових наслідків для осіб, що вчинили діяння «через зміст друкованих видань». Зокрема, у 28 та §29 передбачалися «особливі положення при вчиненні діяння через друковані видання», відповідно до яких: «якщо діяння було вчинено за допомогою періодичного друкованого видання, для якого надано передоплату, то разом із покаранням, передбаченим законом, слід винести вирок про повну або часткову конфіскацію передоплати на користь фонду для бідних населеного пункту, де було вчинено діяння, а саме: у разі вчинення діяння, за яке відповідно до закону передбачено покарання у вигляді тюремного ув'язнення більше ніж на 5 років, - конфіскацію від половини до повної суми такої оплати; у разі вчинення діяння, за яке закон передбачає максимум 5 років тюремного ув'язнення, - конфіскацію від 1000 гульденів до половини суми оплати; при діянні, покарання за яке становить менший строк, - конфіскація від 500 до 1000 гульденів. Крім того, у разі вчинення діяння через періодичне друковане видання може бути прийнято рішення щодо припинення його подальшого випуску на строк до 3 місяців, а у разі особливо обтяжуючих обставин - рішення про його повну заборону. У всіх випадках, коли вчинено діяння через друковане видання, може бути прийнято рішення про повне знищення незаконно випущеного друкованого видання або його частини, а також знищення засобів, які використовувалися для його випуску: обладнання, плит, форм, набору, каменів тощо» [12]. При цьому, згідно із 310 Уложення, вчинення караного діяння, що полягало у розповсюдженні неправдивих відомостей або неправдивого повідомлення інформації як постанови державного органу «через друковане 
видання», значним чином підвищувало суспільну небезпеку цього діяння порівняно із вчиненням його у іншій формі (наприклад, шляхом публічної заяви), що виявилося у підвищенні покарання у вигляді тюремного ув'язнення від 1 до 6 місяців. 3 цього вбачається, що виділення осіб, які мали повноваження щодо випуску у світ і розповсюдження друкованих творів різних видів, в окрему групу було пов'язано із можливістю впливу на громадську думку шляхом випуску у світ друкованої продукції.

З урахуванням цього державне регулювання випуску у світ друкованої продукції, а також iï подальше розповсюдження здійснювалося за рахунок таких законодавчих положень Кримінального уложення 1852 року:

1) кримінально-правові норми, що містили заборони щодо змісту творів, які можуть впроваджуватися в товарний оборот, а саме:

- образа Його Величності, у тому числі образа, богохульство чи насміхання у друкованій продукції, повідомленні чи шляхом розповсюдження малюнків із зображеннями чи написами $(\S 63)$;

- порушення суспільного спокою, що могло виражатися публічно, у присутності багатьох осіб шляхом розміщення у друкованій продукції написів і зображень: а) закликання до неповаги і ненависті проти особи Імператора, проти єдиної державної цілісності Імперії, проти форми правління і державної влади; б) закликання і підбурювання до непослуху і супротиву законам, постановам, судовим рішенням чи рішенням інших державних установ, відмови від податків чи визначених для суспільних цілей завдань (§65);

- втручання у діяльність державних органів (вплив на їх діяльність), вчинене шляхом розміщення певної інформації у друкованій продукції (§80);

- розповсюдження зображень, творів 3 насміханнями, недостовірними відомостями чи спотвореннями фактів з метою спростувати зміст наказів чи рішень влади або таким чином підбурити ненависть чи створити безпідставну скаргу (\$300);

- образа законно визнаної церкви або релігійного товариства, вчинена у друкованих виданнях, розповсюджуваних зображеннях чи листах (§303);

- сприяння релігійній секті, що визнана державою забороненою, вчинене шляхом публікації відповідних матеріалів (§304);

- публікація наклепу у друкованих виданнях, популярних творах чи графічних зображеннях або публікація достовірних, але образливих фактів приватного або сімейного життя, за відсутності необхідності робити це у разі надзвичайних обставин (§489);

- вчинення іншої публічної образи шляхом публікації і розповсюдження у друкованих виданнях, популярних творах чи графічних зображеннях будь-якого роду певних фактів, які не підкріплені доказами, або висловлювань, що можуть спричинити публічний осуд (§491).

2) кримінально-правові норми, що стосувалися незаконного копіювання і розповсюдження творів:

- незаконне здійснення друкованих робіт або робіт тиснення, що могло виявлятися у виконанні будь-якою особою роботи щодо друку чи тиснення без дозволу влади або здійсненні торгівлі чи виробництва, пов'язаного із друком чи тисненням продукції, і яке потребує отримання дозволу (\$326);

- несанкціоноване утримання обладнання для друку, що полягало у використанні ким-небудь станку для друку, ручного друкованого станку з друкованим шрифтом або мідної друкованої машинки, обладнання для літографічного друку, друку під тиском на дереві або чого-небудь іншого, що є придатним для механічного або хімічного копіювання друкованих матеріалів, перелічених у ст. II Уложення, без дозволу органів влади (\$327);

- вчинення діянь, передбачених у $\$ 326$ або $\$ 327$, без отримання дозволу на ведення торгівлі чи заснування фабрики з провадження таких робіт, каралося також згідно із §328;

- відповідно до $\$ 467$ караним визнавалося таке діяння: будь-який незаконний передрук або копіювання чи відтворення літературного чи художнього твору, визнаного таким згідно із законом; при цьому, крім покарання винного, для законного правоволодільця передбачалася компенсація у розмірі вартості незаконно випущених зразків творів;

- публічне виконання драматичного або музичного твору у цілому чи скорочено, або 3 незначними змінами визнавалося караним діянням, що порушує права автора або його правонаступників.

Кримінальне покарання за незаконне розголошення таємниць передбачалося однією нормою, у якій зазначалося про «розкриття довірених особі офіційних секретів», а також «знищення 
особою документа, довіреного їй владою, або повідомлення кому-небудь чогось, що суперечить обов’язкам» (\$102). Згідно із §101 Уложення, це діяння міг також вчинити державний службовець, яким визнавався «той, хто в силу прямого чи опосередкованого державного доручення, під присягою чи без неї, зобов'язаний вести державні справи». Окрім того, передбачалася кримінальна відповідальність за незаконне здобуття інформації, що зберігається у секреті (§316) [12].

Із прийняттям Закону про авторське право на твори літератури, мистецтва і фотографії 26.12.1895 року значно розширився перелік об'єктів авторського права, що підлягали правовій охороні. Літературними творами було визнано книги, брошури, журнали, збірки листів та інші письмові твори, у тому числі кишенькові твори, календарі, звіти, статті. До художніх творів відносились картини, малюнки, плани, архітектурні проекти, інші графічні твори, вироби різьбярства та інші пластичні твори, а також фотографії [4, с. 36]. Так само як і Закон 1846 року, цей нормативно-правовий акт включав у себе кримінально-правові норми, що визначали покарання за посягання на охоронювані об'єкти. Порушення Закону від 1895 року визнавалося злочином, за вчинення якого передбачалося покарання у вигляді штрафу від 100 до 2000 гульденів або арешту від 1 до 6 місяців (§51). Порушення права на фотографію каралося штрафом у розмірі від 5 до 100 гульденів (§52). Додатково до кримінального покарання за порушення авторських прав у §61 Закону передбачалося право автора «за фактом кожного порушення» авторського права звертатися до суду за стягненням відповідної компенсації, що дозволило авторам отримати швидкий i належний захист їх прав та припинення правопорушень, не очікуючи закінчення тривалого кримінального провадження [9]. На підставі $24, \S 33, \S 38, \S 41$ Закону порушенням авторського права визнавалося незаконне оприлюднення твору, його переробка, відтворення, у тому числі в обсягах, більших, ніж це визначено у договорі, публічне виконання або показ творів. У літературі також відзначено про охорону немайнових прав автора і визнання їх порушення кримінально караним діянням $[4$, с. 36]. У той же час не вважалося порушенням виготовлення приватних копій творів без комерційної мети [9].

Розвиток права промислової власності на українських землях, що перебували у складі Австрії, відзначається доволі повільними темпами. Першим загальнодержавним законом у сфері патентного права вважається Закон «Про привілеї» від 15.08 .1852 року [5, с. 49].

Відповідно до §1 цього Закону привілей міг бути виданий на винахід, що міг являти собою новий виріб, новий спосіб чи метод виробництва. Винахід вважався новим, якщо він не був відомий, і відомості про нього не було опубліковано у будь-яких друкованих виданнях до моменту подачі заявки на патент. Згідно із §2 та §5 Закону патент не видавався на винаходи, зміст яких суперечить суспільним інтересам $(\S 13-\S 15)$. Згідно із $\S 38$ порушенням права на привілей вважалося копіювання запатентованого об'єкта, а також продаж незаконно виготовлених (контрафактних) об'єктів чи імпортованих об'єктів такого роду. Власнику патенту законом надавалося право пред'являти вимогу щодо заборони використання контрафактних об'єктів протягом патентного періоду, а також (у тому числі якщо вони отримані з-за кордону) вимагати їх знищення (§39 - §40). Обов’язковим питанням, що потребувало першочергового вирішення під час розслідування таких справ, було питання щодо недійсності чи анулювання патенту, що вимагало підтвердження Міністерства торгівлі. У разі втрати чинності патентом провадження по справі закривалося [11].

Більш прогресивним з погляду охорони прав патентовласників вважається Закон Про охорону винаходів (патентний закон) від 11.01.1897 року. До нього законодавцем було включено багато положень, які і зараз $є$ актуальними. Зокрема, були передбачені положення щодо службових винаходів, а також право службовця-винахідника на отримання винагороди за створення винаходу; отримання патенту надавало виняткове право винахіднику виготовляти відповідний предмет, вводити його в цивільний оборот, продавати і застосовувати; вводилося поняття попереднього користувача - особи, яка на момент подання заявки добросовісно використовувала винахід в Австрії або здійснила підготовку для такого використання. Крім того, саме із цим законом пов'язане виникнення передумов для правової охорони немайнових прав винахідника - відповідно до §29 Закону володілець патенту позбавлявся права на патент, якщо було доведено, що він не був справжнім винахідником або його правонаступником. За порушення прав власника патенту Законом передбачалося покарання у вигляді штрафу у розмірі від 500 до 2000 гульденів або тюремне ув'язнення на строк від 3 місяців до 1 року [5, с. 51-53].

Правова охорона промислових зразків здійснювалася відповідно до Імператорського патенту від 07.12.1858 року, а пізніше - Закону від 23.05.1865 року. Зразком (моделлю) визнавався «будь-який малюнок і візерунок, який стосується форми промислових виробів і $є$ придатним 
до відтворення». Порушення виняткових прав на промисловий зразок каралося штрафом, а також тюремним ув'язненням. Правова охорона торгової марки була передбачена згідно із Законом від 07.12.1858 року про охорону промислових знаків, а згодом - Законом від 06.01.1890 року про охоронні марки. Караним визнавалося порушення діяння щодо прав на зареєстровану торгову марку, що каралося штрафом або тюремним ув'язненням на строк від 3 місяців до 1 року. Додатково потерпілий мав право вимагати відшкодування шкоди, розмір якої встановлював суд [5, с. 54-56].

Висновки. Варто відзначити, що побудова норм Кримінального уложення 1852 року, так само як і положень кримінального законодавства Російської імперії, відбувалася за принципом пріоритетності інтересів держави, а не людини. Це зумовлюється передусім монархічною формою державного правління обох держав, яка передбачає пріоритетність саме державного інтересу над приватним. Очевидно, що світове суспільство дійшло усвідомлення значення людини як найвищої соціальної цінності тільки після завершення Другої Світової війни, що знайшло своє вираження у Загальній декларації прав людини [6]. Важливо, що саме пріоритетність державного інтересу над приватним у цей історичний період безпосередньо вплинула на основні підходи до формування концепції правової охорони об'єктів права інтелектуальної власності. Не зважаючи на те, що законом передбачалася можливість захисту прав створювача об'єкта права інтелектуальної власності (наприклад, у формі цивільно-правової компенсації), у центрі правової охорони перебував не суб'єкт, а об'єкт права інтелектуальної власності. Це виявлялося у тому, що кримінально-правова охорона була спрямована передусім на забезпечення реалізації державного контролю над оборотом друкованої продукції, а також інших об'єктів права інтелектуальної власності, а не на захист прав створювачів відповідних об'єктів. Наприклад, у літературі відзначається про неодноразові факти відмови держави від надання правової охорони тому чи іншому твору з підстав невідповідності його утвердженій в країні релігії або «принципам справедливості», які визнані у країні єдино вірними [10]. Поступово цей підхід був замінений іншим, за якого центральною і ключовою ланкою у правовій охороні об'єктів права інтелектуальної власності був автор (створювач об’єкта права інтелектуальної власності), що відбулося у II половині XIX ст. 3 розробленням міжнародних стандартів правової охорони і прийняттям Бернської конвенції у 1886 році. Саме становлення такого підходу вплинуло на розуміння створювача об'єкта права інтелектуальної власності як потерпілого, тобто обов'язкового компонента об'єкта кримінально-правової охорони.

\section{Список використаних джерел:}

1. Берзін П.С. Джерела карного законодавства Австрійської та Австро-Угорської імперій, що застосовувались на українських землях. Вісник кримінального судочинства. 2018. № 1. C. $68-76$.

2. Берзін П.С. Кримінальне право України. Загальна частина : підручник : у 3-х т. Т. I. Загальні засади. 2-ге вид. виправ. та доп. Київ : ВД «Дакор», 2019. 562 с.

3. Волинець Р.А. Кримінально-правова охорона фондового ринку: сучасний стан та перспективи вдосконалення : монографія. Київ : ВД Дакор, 2018. 452 с.

4. Гулкевич В.Д. Кримінально-правова охорона авторського права і суміжних прав : дисертація на здобуття наукового ступеня кандидата юридичних наук : спеціальність - 12.00 .08 кримінальне право та кримінологія; кримінально-виконавче право ; Львівський національний університет імені Івана Франка. Львів, 2008. 218 с.

5. Довгань Г.В. Становлення та розвиток законодавства України про інтелектуальну власність (історико-правовий аспект) : дисертація на здобуття наукового ступеня кандидата юридичних наук : спеціальність - 12.00.01 - теорія та історія держави і права ; історія політичних і правових вчень ; Львівський національний університет імені Івана Франка. Львів, 2008. 222 с.

6. Загальна декларація прав людини від 10.12.1948 року. Офіційний вісник України. 2008, № 93 (15.12.2008), ст. 3103.

7. Нерсесян А.С. Кримінально-правова охорона прав інтелектуальної власності: Монографія. Хмельницький : Вид-во Хмельницького університету управління та права, 2010. 192 с.

8. Харченко В.Б. Кримінально-правова охорона прав на результати творчої діяльності та засоби індивідуалізації в Україні : монографія. Харків : ХНУ імені В. Н. Каразіна, 2011. 480 с.

9. Michael Löffler. Urheberrechtsverletzungen im Internet. Rechtlich, technisch und wirtschaftlich betrachtet. URL: http://www.law.tuwien.ac.at/DA_Loeffler.pdf.

10. Rozwój historyczny praw własności intelektualnej z perspektywy interesu publicznego. URL: https://www.ksiegarnia.beck.pl/media/product_custom_files/8/0/8084-interes-publiczny-i-jego- 
oddzialywanie-na-powstanie-tresc-i-wykonywanie-praw-wlasnosci-intelektualnej-arkadiusz-michalakdarmowy-fragment.pdf.

11. RudolfKlostermann. DiePatent-gesetzgebung allerländer.URL:https://books.google.com.ua/ books?id=GMclWSzIbkAC\&pg=PA262\&lpg=PA262\&dq=Patentgesetz $+\% \mathrm{C} 3 \% 96$ sterreich $+1852 \&$ source $=$ bl\&ots $=$ ZkegI9CWDd\&sig $=91$ aa6keTYF9ri9ZVezGTwZfqTGg\&hl $=$ ru\&sa $=$ X\&ved $=$ 2ahUKEwiCper3iNTfAhVtwIsKHYJiCHYQ6AEwBHoECAYQAQ\#v=onepage\&q=Patentgesetz $\%$ $20 \% \mathrm{C} 3 \% 96$ sterreich $\% 201852 \& \mathrm{f}=$ false.

12. Strafgesetz 1852 (Österreich). URL: https://de.wikisource.org/wiki/Strafgesetz_1852_ (\%C3\%96sterreich).

УДК $351 / 354 ; 34.07$

DOI https://doi.org/10.32844/2618-1258.2019.5-2.3

ТИХОМИРОВ Д.О.

\section{ДЕЯКІ АСПЕКТИ ОСМИСЛЕННЯ БЕЗПЕКИ ТА ЇЇ ГАРАНТІЇ}

У статті осмислюються проблеми плюралістичності наукового та нормативно-правового розуміння понять безпека, небезпека та гарантія безпеки. 3'ясовуються особливості їх співвідношення та змістовного наповнення. Метою статті $\epsilon$ осмислення окремих аспектів розуміння безпеки, небезпеки та гарантії безпеки, правової безпеки зокрема. Методологія дослідження склала сукупність методів, які охоплюють: діяльнісний, метод герменевтики, метод порівняння та метод абстрагування. У «статичному» розумінні безпека розглядається в зіставленні з певними об'єктами (матеріальним та нематеріальними) та суб'єктами як їх характеристика (властивість) риса. В «динамічному» розумінні безпека пов'язується з певною діяльністю, спрямованою на безпеку (ії суб'єктами, засобами, заходами, нормативами, метою тощо), інакше кажучи, на гарантію (захист, охорону) безпеки. 3'ясовано, що в разі обмеження чи уточнення поняття «безпека» набуває всеохоплюючого характеру чи значення, і важко виявити ті явища та процеси, які не охоплюються цим поняттям. 3 іншого боку, неможливо виключати такий аспект розуміння безпеки. Безпека та їі гарантія в різних варіаціях співвідноситься з існуванням, розвитком, цілісністю, незалежністю, спокоєм об'єкта безпеки та відсутністю небезпеки (загроз, ризиків). Безпека і небезпека мають взаємозалежні виміри, відносні одне одного значення. Так, безпека - це відсутність небезпеки, небезпека за своїм впливом на безпеку - гранична, неприпустима, надмірна, мінімальна, обмежена до прийнятного рівня. Проблеми правової безпеки та ії гарантія потребують подальшого наукового осмислення й не тільки в напрямі з'ясування загального з їх міждисциплінарним розумінням, але й виявлення своєрідності саме правового розуміння, його імплементації в понятійно-категоріальний апарат юридичної науки, зокрема через співвідношення з такими традиційними юридичними науковими конструкціями як правопорядок, злочинність, правовий вплив, правове регулювання, функції права та держави, гарантії тощо.

Ключові слова: безпека, небезпека, загрози, захищеність, законодавство, забезпечення безпеки, об 'єкти безпеки, суб'єкти безпеки.

The article deals with the problems of pluralistic scientific and regulatory understanding of the concepts of safety, danger and security. The peculiarities of their correlation and content are explained. Goal. The purpose of the article is to understand some

(С) ТИХОМИРОВ Д.О. - кандидат юридичних наук, докторант докторантури та аспірантури (Національна академія внутрішніх справ) 